\title{
Achieving selectivity in space and time with DNA double-strand- break response and repair: molecular stages and scaffolds come with strings attached
}

\author{
S. Liang ${ }^{1} \cdot$ S. R. Esswein ${ }^{1,2} \cdot$ T. Ochi ${ }^{1,3} \cdot$ Q. Wu ${ }^{1} \cdot$ D. B. Ascher ${ }^{1} \cdot$ D. Chirgadze ${ }^{1}$. \\ B. L. Sibanda ${ }^{1} \cdot$ T. L. Blundell ${ }^{1}$ (iD
}

Received: 8 July 2016/Accepted: 30 August 2016/Published online: 30 September 2016

(c) The Author(s) 2016. This article is published with open access at Springerlink.com

\begin{abstract}
When double-strand breaks (DSBs) in DNA remain unrepaired, catastrophic loss of genes occurs, leading to translocations, mutations and carcinogenesis. If a sister chromatid is not available at the DNA DSB, nonhomologous end joining (NHEJ) is used to join broken ends. The NHEJ pathway comprises synapsis, end processing and ligation. Here, we ask how DSBs in DNA are repaired efficiently. We suggest that colocation of proteins is achieved over time by the following components: stages, where the main actors are assembled, scaffolds that are erected quickly around broken parts to give access, and strings that tether proteins together. In NHEJ, a stage is provided by the Ku heterodimer interacting with DSBs and several other proteins including DNA-PKcs, APLF, BRCA1 and PAXX. A further stage, DNA-PKcs, links the kinase with DNA, Ku, PARP1, BRCA1 and Artemis. A temporary scaffold facilitates repair and is constructed from XRCC4/XLF filaments that bridge Ku bound at DSB ends. LigIV bound to XRCC4 C-termini likely terminates the scaffold, bringing LigIV close to the DNA broken ends. A string, provided by the Artemis C-terminal region, is intrinsically disordered but includes short linear "epitopes" that recognise DNA-PKcs, LigIV and PTIP, so keeping
\end{abstract}

T. L. Blundell

tlb20@cam.ac.uk

1 Department of Biochemistry Sanger Building, University of Cambridge, 80 Tennis Court Road, Cambridge CB2 1GA, UK

2 Present Address: Departments of Biological Chemistry and Chemistry and Biochemistry, UCLA-Department of Energy (DOE) Institute for Genomics and Proteomics, UCLA, Los Angeles, CA 90095, USA

3 Present Address: MRC Laboratory of Molecular Biology, Cambridge CB2 0QH, UK these components nearby. We show that these stages, scaffolds and strings facilitate colocation and efficient DSB repair. Understanding these processes provides insight into the biology of DNA repair and possible therapeutic intervention in cancer and other diseases.

Keywords Non-homologous end joining - DNA repair . DNA-PKcs · XRCC4 - Artemis · Protein-protein interactions

\section{Introduction}

DNA double-strand breaks (DSBs) are the most severe form of DNA damage in eukaryotic cells and are generated by ionising radiation, reactive oxygen species and DNA replication across nicks [1]. DSBs can lead to cell death, and erroneous repair may result in carcinogenesis through chromosomal translocation or modification. Non-homologous end joining (NHEJ) and homologous recombination (HR) are the two major pathways of DSB repair in human cells. HR functions mainly in the late $\mathrm{S} / \mathrm{G} 2$ phases of the cell cycle due to the requirement for a sister chromatid. In contrast, NHEJ repairs DSBs directly without a DNA template and can function throughout G1/early S phases [1].

The NHEJ process comprises DNA synapsis, end processing and ligation [2]. During synapsis, Ku70/Ku80 heterodimers assemble around and maintain proximity of broken DNA ends [3]. DNA-dependent protein kinase catalytic subunit (DNA-PKcs), a PI3-kinase-related kinase, is recruited through interaction with the Ku80 C-terminus to form DNA-PK [4, 5]. Two DNA-PK complexes are thought to hold DNA ends close together [6]. DNA-PKcs phosphorylates itself and various other proteins, including NHEJ components. End processing involves nucleases 
such as Artemis, which exhibits endonuclease activity after activation by DNA-PKcs phosphorylation [7]. The final ligation step is mediated by DNA ligase IV (LigIV) in a stable complex with dimeric XRCC4 [8]. XLF/Cernunnos also interacts with XRCC4 and enhances LigIV DNA ligation, promoting NHEJ [9, 10].

Structural and functional studies of individual components in NHEJ previously reported include DNA-PKcs [11], LigIV [12], XLF [13] and XRCC4 [14]. We have investigated the following binary complexes: LigIV/ XRCC4 [14], XRCC4/XLF [15], LigIV/Artemis [16] and DNA-PKcs/Ku80 C-terminus [11; Sibanda BL, Chirgadze DY, Ascher D, Blundell TL, In preparation]. Last year we discovered PAXX [17], an additional component involved in NHEJ (Fig. 1).

These studies and others (e.g. [18, 19]) still leave unanswered questions, including how NHEJ components are coordinated across space and time throughout synapsis, end processing and ligation. We observed three different mechanisms that may ensure appropriate spatial colocation of components: stages that are preformed stable structures where the main actors gather and engage, scaffolds that are constructed quickly and disassembled easily to facilitate cell responses, and strings that tether components together. For NHEJ, these include:

1. A stage comprised of $\mathrm{Ku}$ heterodimer, interacting with DNA broken ends and binding a variety of components including DNA-PKcs, aprataxin- and PNKP-like factor (APLF), XLF, BRCA1 and PAXX.

2. A further stage, DNA-PKcs, which interacts with $\mathrm{Ku}$ heterodimer, DNA, PARP1, BRCA1, Artemis and other components, often depending on post-translational modification and binding of other factors.

3. A scaffold assembled from protein filaments of alternating XRCC4 and XLF dimers to bridge $\mathrm{Ku}$

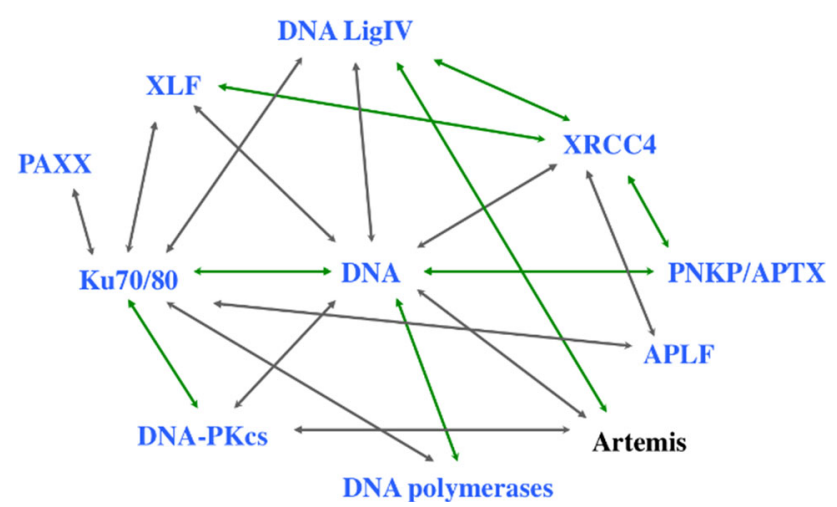

Fig. 1 NHEJ protein network. Arrows indicate a known interaction. Blue labels indicate the structure has been determined. Green arrows indicate complexes with experimentally defined structural interactions (Color figure online) heterodimers. This bridging is regulated by LigIV, which the tails of XRCC4 bind tightly, therefore bringing LigIV close to DNA broken ends.

4. An intrinsically disordered string comprising the 300-residue C-terminal region of Artemis. Foldable regions of the Artemis C-terminus interact with DNAPKcs, LigIV and PTIP, which may keep these components close to the DNA repair process in order to be available to function when needed.

Apart from ensuring correct colocation at the appropriate time, we have contended that the complexity of such assemblies is selectively advantageous [20-22]. Binary interactions in regulatory or signalling systems would occur opportunistically in the crowded environment of the cell, giving rise to noise in the system. Conversely, cooperative formation of multiprotein systems is less likely to form opportunistically, especially if they have many components and ordered-assembly mechanisms.

Here, we show that such stages, scaffolds and strings have complementary roles, often binding to the same partners but operating in different ways over space and time. Understanding spatial and temporal organisation of NHEJ may provide insight into whether such mechanisms are universal for mediating colocation in other complex regulatory systems.

\section{Assembling and coordinating the actors in NHEJ}

Spatial organisation of molecular assemblies in NHEJ has been studied using nanoelectrospray mass spectrometry, small-angle X-ray scattering (SAXS), X-ray crystallography, NMR and cryo-electron microscopy (cryo-EM). Cumulative insight from these techniques allows us to understand further how NHEJ proceeds efficiently over time.

\section{A stage: Ku heterodimer forms a platform with DNA}

The Ku heterodimer assembles around broken DNA ends, forming a stage in which the core ring structure is responsible for interacting with APLF, WRN, XLF, PAXX and BRCA1, and the C-terminal domain of Ku80 interacts with DNA-PKcs [4, 5, 23]. We are using X-ray crystalstructure analysis, cryo-EM and biophysical approaches to define the interactions between components and describe the subsequent structural changes. We comment here on two of the proteins that assemble on this stage and whose interactions have been topics of recent discussion.

PAXX, identified recently in our lab as PAralog of XRCC4 and XLF by using structure-based homology 
searches, interacts with $\mathrm{Ku}$ to promote DNA-DSB repair [17, 24, 25] (Fig. 2). Using an in vitro pull-down assay and biochemical analysis, we showed that the PAXX C-terminus (residues 177-204) interacts with the core ring of Ku in a DNA-dependent manner. We suggested this interaction might be regulated by phosphorylation of the PAXX C-terminus by DNA-PK. In collaboration with the laboratory of Dr. Steve Jackson [17], we demonstrated that PAXX is recruited to DNA-damage sites in cells, and PAXX depletion leads to DSB-repair defects and hypersensitivity to ionising radiation. Using RNA interference and CRISPR-Cas9 to generate PAXX-/- human cells, we showed that PAXX functions with XRCC4 and XLF to mediate DSB repair and cell survival in response to DSBinducing agents. PAXX promotes Ku-dependent DNA ligation in vitro and assembly of core non-homologous end-joining (NHEJ) components on damaged chromatin in cells.

Two groups have reported an interaction between BRCA1 and $\mathrm{Ku}[26,27]$. BRCA1 functions as a tumour suppresser gene, and patients carrying the germline or somatic mutations have high risk of developing breast and ovarian cancer [28]. The expression and phosphorylation of BRCA1 is cell cycle-dependent with the highest level at $S$ and $M$ phases [29]. BRCA1 recruitment is important for influencing Ku70/80 retention at the DNA-damage sites and promoting the chromosomal G1 phase of NHEJ. The exact region in BRCA1 responsible for this interaction with $\mathrm{Ku}$ was reported as amino acids 1-200 in one report [27] but more recently as $262-552$ in the other [26]. Our ongoing objective is to define the region of BRCA1 responsible for the interaction with $\mathrm{Ku}$.

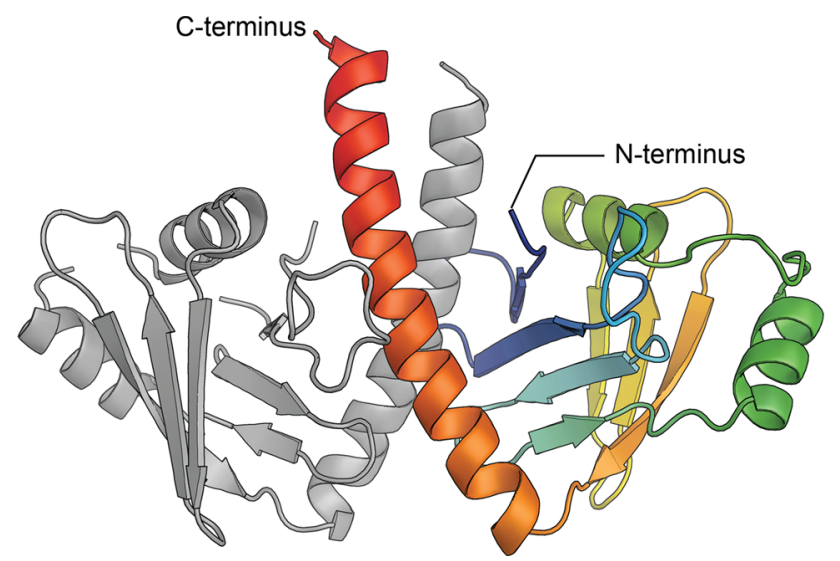

Fig. 2 Structure of PAXX. The crystal structure of PAXX homodimer (PDB code: $3 \mathrm{WTD}$ ) is presented using a cartoon representation. One of the chains is indicated by rainbow colour; the $\mathrm{N}$ - and C-termini are blue and red, respectively (Color figure online)

\section{A second stage: DNA-PKes}

In 2010, we described the crystal structure of the $\sim 4000$ amino-acid chain of DNA-PKcs complexed with the $\mathrm{C}$-terminus of $\mathrm{Ku} 80$ at low resolution, in which the two molecules in the asymmetric unit have slightly different relative positions of the head domain and the large circular structure of HEAT repeats that comprise the stage [11]. More recently, we extended the study to a higher resolution, allowing the chain to be traced. We are using both $\mathrm{X}$-ray crystallography and cryo-EM to define how other molecules, such as $\mathrm{Ku}$ and DNA, assemble on this stage. Interestingly, in the $S$ phase, BRCT domains of BRCA1 (see "The strings" section) are reported to interact with DNA-PKcs (near S2056) in a phosphorylation-independent manner to block DNA-PKcs autophosphorylation, reducing NHEJ and increasing HR [30].

\section{A scaffold: XRCC4/XLF filaments}

XRCC4 and XLF are both homodimers with similar architectures, including the $\mathrm{N}$-terminal head domains and C-terminal tail regions [13, 14]. Our group [12, 15] and others [31-35] have shown by mutagenesis study, size chromatography, SAXS, native mass spectrometry and X-ray crystallography that XRCC4 and XLF dimers interact through their head domains, leading to the formation of XRCC4/XLF filaments, elongation of which is regulated by LigIV [12]. The alternating XRCC4/XLF helical polymers are flexible, and multiple copies of filament can assemble into cylinders with a diameter that may accommodate and colocate other components of NHEJ (Fig. 3). As a result, XRCC4/XLF filaments may function as a scaffold to allow the alignment of the two broken DNA ends and the local assembly of NHEJ components to enhance LigIV function.

\section{The strings}

\section{Artemis C-terminal region}

Artemis, which belongs to the metallo- $\beta$-lactamase superfamily, is the major nuclease involved in the end-processing step of NHEJ. It has been estimated that Artemis repairs $10-15 \%$ of DSBs generated by IR [36]. The Artemis gene DCLREIC was first discovered mutated in patients who had radiosensitive-severe combined immunodeficiency (RS-SCID) and Athabascan SCID (SCIDA) [7]. It was later found that Artemis is the essential endonuclease that opens the hairpin intermediate structure upon stimulation by DNA-PKcs during V(D)J recombination [37]. The nuclease also has intrinsic $5^{\prime}$ exonuclease activity [38] and weak endonuclease activity on ssDNA 

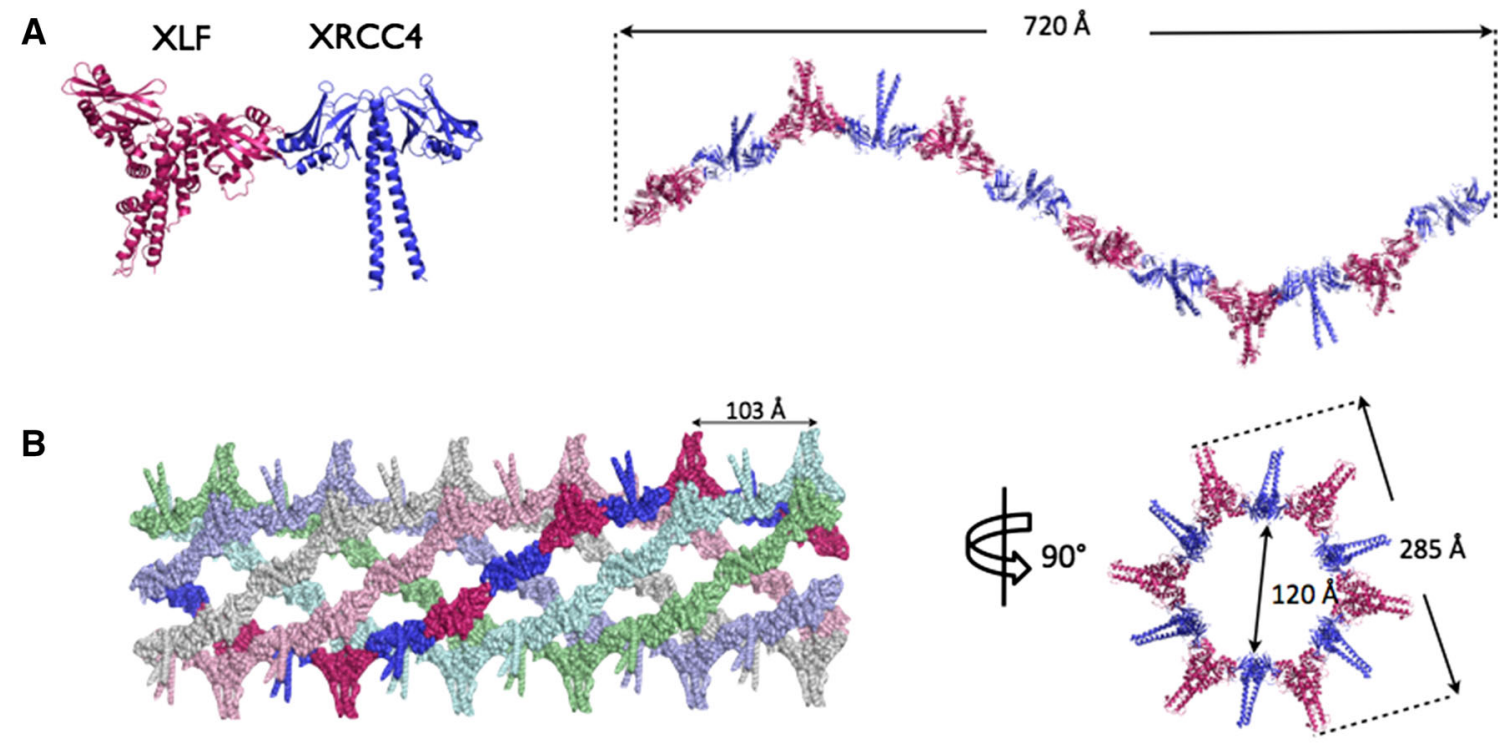

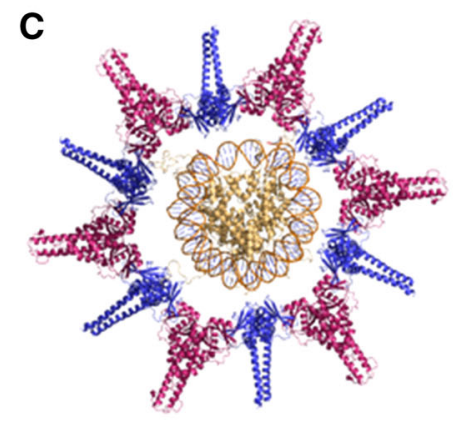

Nucleosome
(PDB code: IKX5)

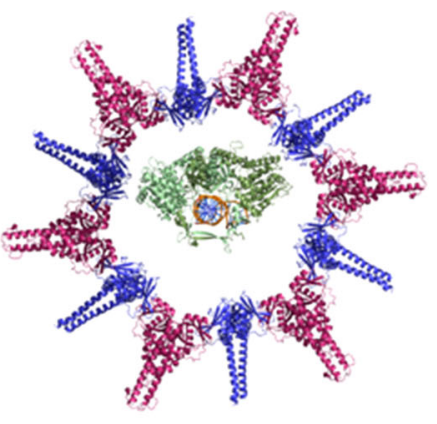

Ku70/80 heterodimer (PDB code:IJEY)

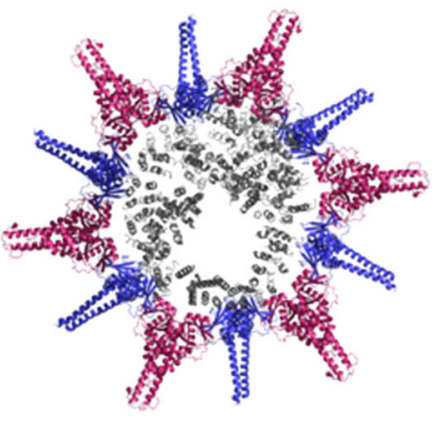

DNA-PKcs (PDB code: 3KGV)
Fig. 3 XRCC4 and XLF. In our crystal structure, alternating XRCC4/XLF helical polymers can assemble into cylinders with diameters that may accommodate and colocate other components of NHEJ (PDB ID: 3W03). a XLF and XRCC4 dimers interact through their head domains to form a helical XRCC4/XLF filament. b The

in vitro, which is likely stimulated when forming a complex with DNA-PKcs [39].

The Artemis structure can be divided into two regions, each accounting for approximately half of its size (Fig. 4). These regions correspond to the $\mathrm{N}$-terminal nuclease, adopting $\beta$-metallo-lactamase and $\beta$-CASP domains [40] homologous to RNaseJ, Apollo and SNM1A, and a C-terminal region, which has no enzyme activity but is nevertheless indispensable for normal Artemis function [41]. IUPRED (Prediction of Intrinsically Unstructured Proteins) [42] predicts the C-terminal region of Artemis to be mostly intrinsically disordered, and ANCHOR (Prediction of Protein Binding Regions in Disordered Proteins) [43] analysis predicts several short regions within the intrinsically disordered C-terminal region to bind globular or structured protein partners (Fig. 5). filaments assemble as a cylinder in the crystal structure. The view perpendicular to the filament axis is shown with a single filament. c The central space created by the filament could potentially accommodate nucleosome, $\mathrm{Ku}$ and DNA-PKcs

\section{Artemis}

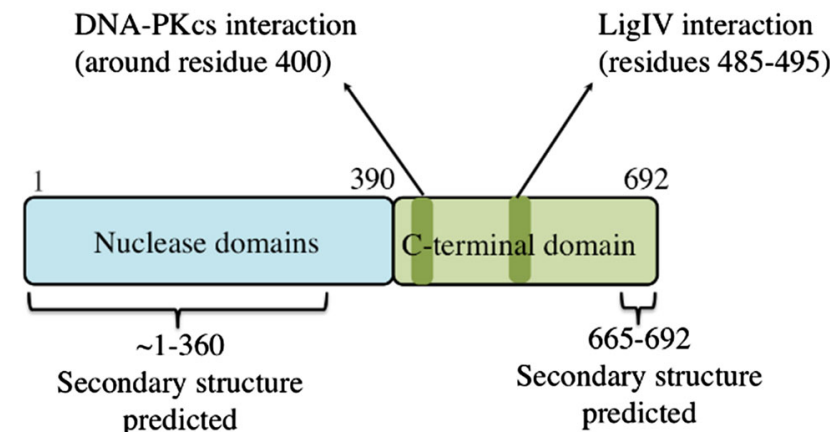

Fig. 4 Schematic of the structure of Artemis: the nuclease in the $\mathrm{N}$-terminal region and the intrinsically disordered C-terminal region. Artemis recognises other NHEJ components including DNA-PKcs and LigIV via the indicated regions that undergo concerted folding and binding 


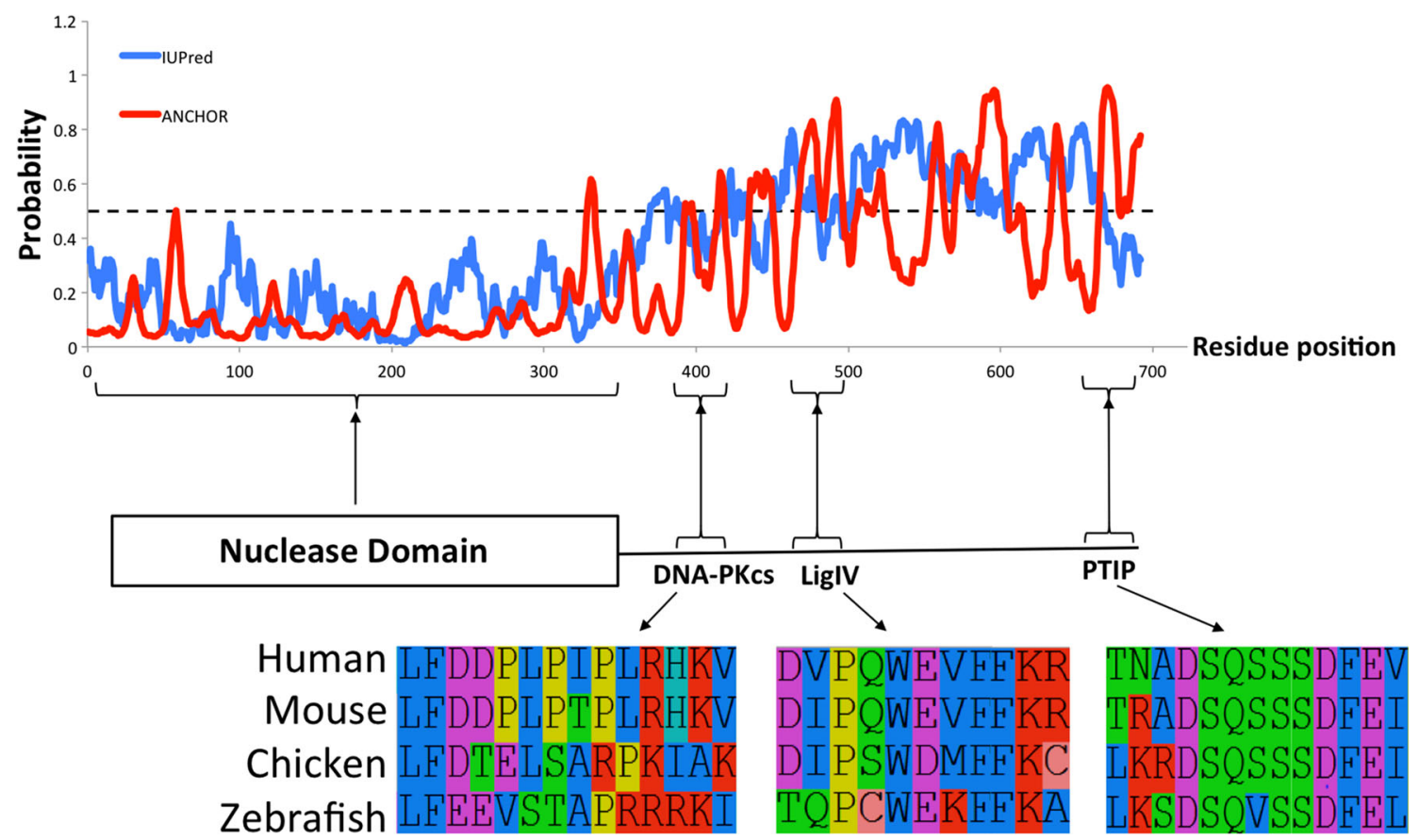

Fig. 5 IUPred and ANCHOR analysis of Artemis with sequence alignment. The $\mathrm{C}$-terminal region of Artemis is predicted to be extensively intrinsically disordered according to IUPred. ANCHOR

We previously showed that Artemis residues 485-495 undergo concerted folding and binding with the first two helices of LigIV to form a three-helix bundle (Fig. 6). Residue W489 of Artemis forms a hydrogen bond with D18 of LigIV, stabilised by interactions between F492/ F493 of Artemis and F49/F42 of LigIV. Moreover, P487 of Artemis resides in the hydrophobic pocket formed by L53, A52 and F49 of LigIV [16]. analysis shows that within the intrinsically disordered region, several segments are likely to interact with other proteins. Sequence alignment also shows that many of these segments are conserved

Although Artemis was predicted to interact with DNAPKcs via residues 399-404 [44], recent pull-down results from our group show that residues 399-404 are not sufficient. While peptides containing residues $399-408$ and 399-426 of Artemis could not pull down DNA-PKcs, residues 385-413 of Artemis could do so, and even showed a stronger interaction with DNA-PKcs compared to fulllength Artemis, indicating that residues that are $\mathrm{N}$-terminal
Fig. 6 Interaction between LigIV and Artemis. The crystal structure of the catalytic domains of LigIV (orange) and the Artemis fragment (aminoacid residues 485-495; silver) is shown on the left. The interaction of the first two helices of LigIV with Artemis is shown in close view on the right (Color figure online)

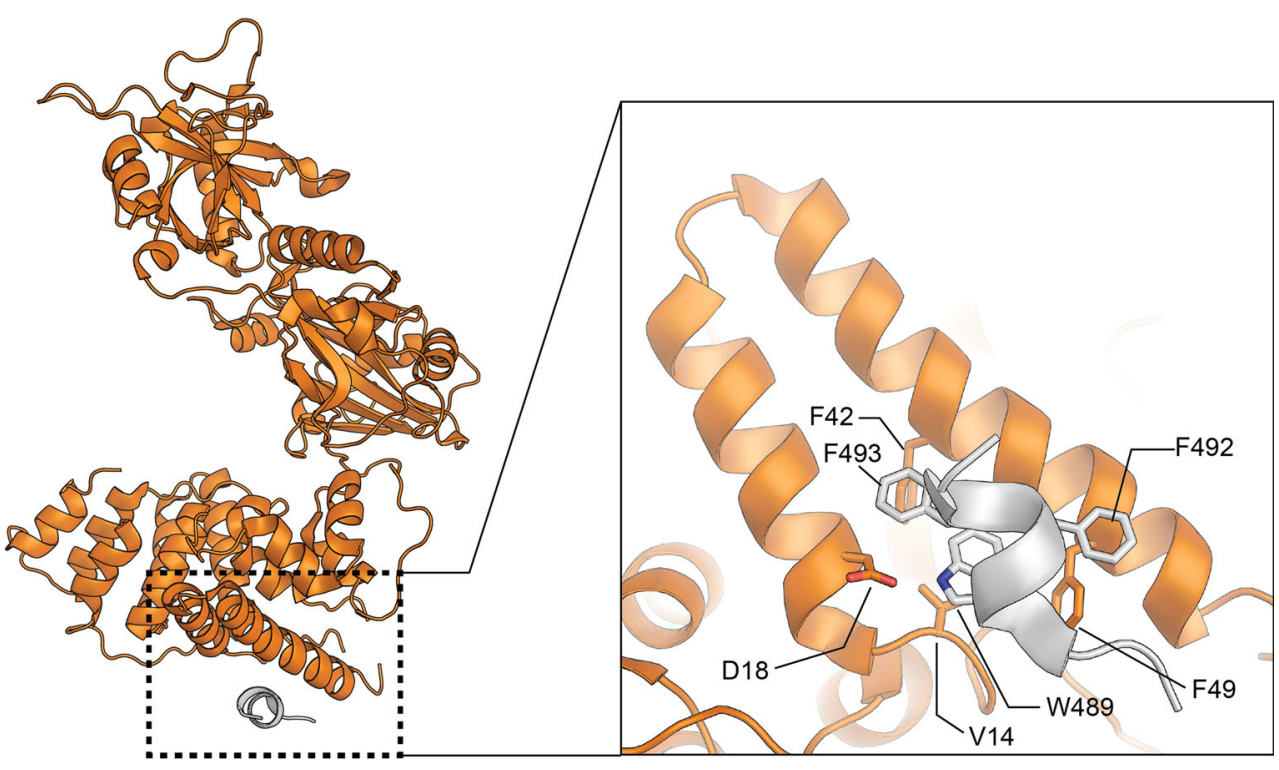


to 399-404 are needed for the Artemis/DNA-PKcs interaction. Furthermore, residues 641-660 of Artemis may bind to the second BRCT domain of an adaptor protein, PTIP, via phosphorylation [43].

Thus, it is likely that the Artemis C-terminus binds to several key components, including DNA-PKcs, LigIV and PTIP [45], facilitating colocation of these components with broken DNA ends. The list may be longer since other studies reveal that the Artemis C-terminal region interacts with other proteins. For example, it was shown that Artemis binds to the Mre11/Rad50/Nbs1 complex (MRN complex) in an ATM-dependent manner under ionising radiation [46]. Although the precise binding region is not defined, it is likely that the Artemis C-terminus is involved given that hyperphosphorylation of Artemis, especially S645 of the SQ/TQ site on the C-terminal region, is dependent on ATM. Additionally, Artemis was co-immunoprecipitated with $\mathrm{Nbs1}$, and Nbs1/Mre11 were coimmunoprecipitated with Artemis reciprocally [46].

\section{$A P L F$}

APLF (Aprataxin- and-PNK-Like Factor) similarly includes multiple binding sites throughout the protein, which facilitate its function both as a stabiliser for the NHEJ holo-complex at DNA-damage sites and as a stimulator of DNA-end ligation [23, 47]. The N-terminal FHA domain of APLF interacts with XRCC4 in a phosphorylation-dependent manner [48]. The amino acid sequence of a large region of APLF in between the structured $\mathrm{N}$ - and C-terminal regions is predicted to be intrinsically disordered and is poorly conserved in evolution (Fig. 7). However, a short sequence (residues 182-192) in this region is conserved in evolution from the sponge (Amphimedon queenslandica) to human. This conserved sequence is important for the interaction with $\mathrm{Ku}$ [23, 49-51], likely through concerted folding and binding. Consequently, this binding site within the intrinsically disordered region of APLF facilitates colocation of the $\mathrm{Ku}$ heterodimer with regions of APLF that have globular structures.

\section{BRCAI}

BRCA1 contains 1863 residues with the two most conserved domains in BRCA1 located at the $\mathrm{N}$ - and C-termini. The N-terminal RING domain, which forms a heterodimer with another RING domain from BARD1 [52], functions as an E3 ubiquitin ligase [53, 54]. The N-terminal region (1-304) was also recently found to bind the protein OLA1 during centrosome regulation [55]. The $\mathrm{C}$-terminal region of BRCA1 contains tandem BRCT domains, which appear to bind DNA-PKes in a non-phosphorylation-dependent manner, as discussed above, and also bind phosphopeptides containing the pSXXF motif [56-58]. We recently determined the structure of the complex of BRCA1 with the C-terminal phosphopeptide of Abraxas (Fig. 8) [59]. Abraxas is part of BRCA1-A complex facilitating the recruitment of BRCA1 to the DNA-damaged site. In collaboration with Dr. Bin Wang (MD Anderson Cancer Center, Houston, TX), we demonstrated that ionising-radiation-induced and ATM-dependent phosphorylation of a serine residue of Abraxas next to the pSPxF motif induces dimerisation of the BRCT/Abraxas complex. Mutation of the ionising-radiation-induced phosphorylation site of Abraxas leads to a deficiency in BRCA1 accumulation and cellular sensitivity to ionising radiation. These findings suggest a novel role of the BRCT/Abraxas complex in the DNA-damage response [46].

Protein interactions within the N-terminal and C-terminal domains of BRCA1 facilitate its role in the DNAdamage response and DNA repair, while the long and less conserved flexible region between these domains provides additional sites for more dynamic and regulated protein interactions (Fig. 9). This disordered region contains the nuclear localisation signal (NLS; amino-acid residues 500-508) [60], PALB-interaction site (amino-acid residues 1397-1424) [61, 62] and phosphorylation sites that are targeted by ATM, Chk2, Cdk2 and DNA-PK at different phases of the cell cycle [63-67]. Although the function of these phosphorylation events is not understood completely, key phosphorylation events include the following: S1423 is phosphorylated by ATM for check-point G2/M function [66], and S988 is phosphorylated by Chk2 [65] for release from Chk2 and HR activity [65, 68]. Thus, the flexible inter-domain region of BRCA1 functions as a string to tether proteins for use as needed.

\section{Discussion}

In order for NHEJ to function accurately, spatial and temporal organisation of NHEJ proteins should be as efficient as possible. This is achieved by colocation of components through macromolecular stages, scaffolds and strings. Despite efforts to understand the spatial assembly of NHEJ complexes by observing their structures, the exact coordination of NHEJ proteins at a DSB site remains unclear. This is due to the dynamic and complex nature of NHEJ proteins, which should gather in a DSB-dependent manner and also disassemble quickly after DNA damage is repaired. Therefore, many NHEJ protein-protein interactions are weak or require the presence of DNA. Moreover, the proteins may assemble differently depending on the type of DNA damage. To observe such a flexible and dynamic biological system, we need to design DNA 


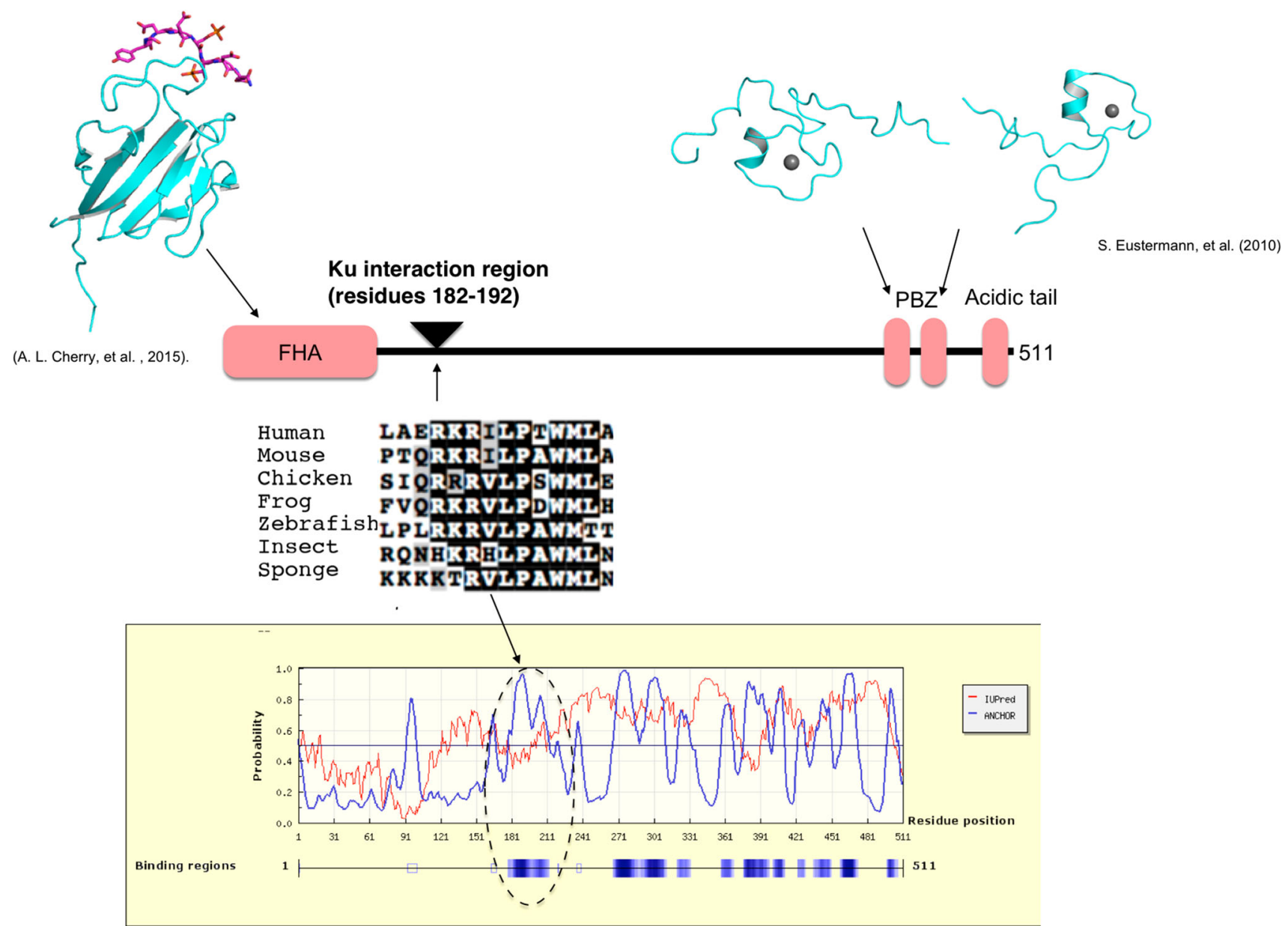

Fig. 7 Domain and interaction sites of APLF. Crystal structures of the FHA domain [48] and PAR-binding zinc-finger (PBZ) [74] of APLF are shown. The Ku-interaction region with sequence alignment is indicated, along with other potential interaction regions predicted by Anchor [75]

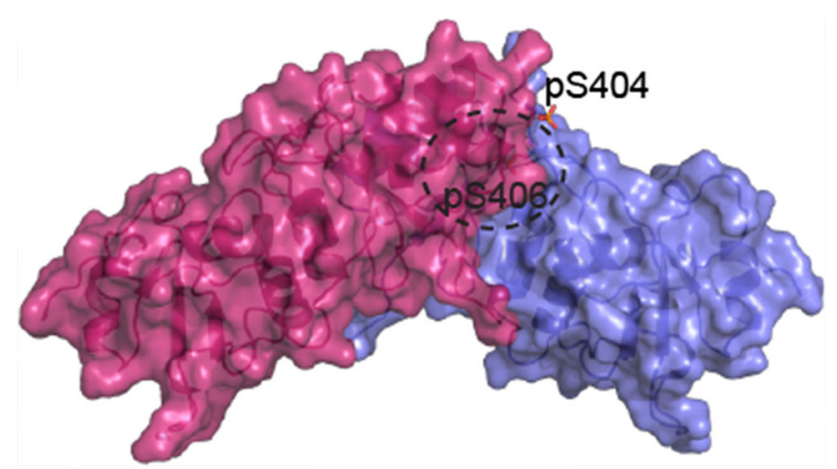

Fig. 8 Dimerisation of two BRCT/Abraxas complexes. The surface representation of two BRCT/Abraxas complexes is shown in pink and blue, respectively (PDB code: 4Y18). The motif-interaction site, which contains phosphorylated S406 (pS406), is indicated by the circle formed from a dashed line. Phosphorylation at S404 is indicated as pS404 (Color figure online)

structures that we would like to study, "freeze" intermediate states of the NHEJ process, for instance, using mutations or crosslinking, and sort heterogeneous samples according to structural state. These are extremely challenging tasks for X-ray crystallography. However, recent advances in cryo-EM offer an attractive approach to overcome these difficulties.

Nevertheless, the spatial organisation of NHEJ complexes is better understood than the temporal organisation of NHEJ. Varying models for NHEJ recruitment have been proposed, and our view is that NHEJ is not a pre-programmed process, though it does require the sequential recruitment of stages, scaffolds and strings. The scaffold proteins may have multiple weak interactions with the stage proteins, therefore permitting stabilisation of the scaffolds only when the complete stage is assembled. Alternatively, the interactions may be regulated through allostery involving conformational change; DNA-PKcs conformational changes appear to be activated by posttranslational modification, including auto-phosphorylation. To study the temporal organisation of NHEJ proteins, it will be necessary to exploit single-molecule approaches. Indeed, the synapsis by core NHEJ proteins [69] and a dynamic nature of the filament formation of XRCC4 and XLF, which are hard to be visualised by current structural 


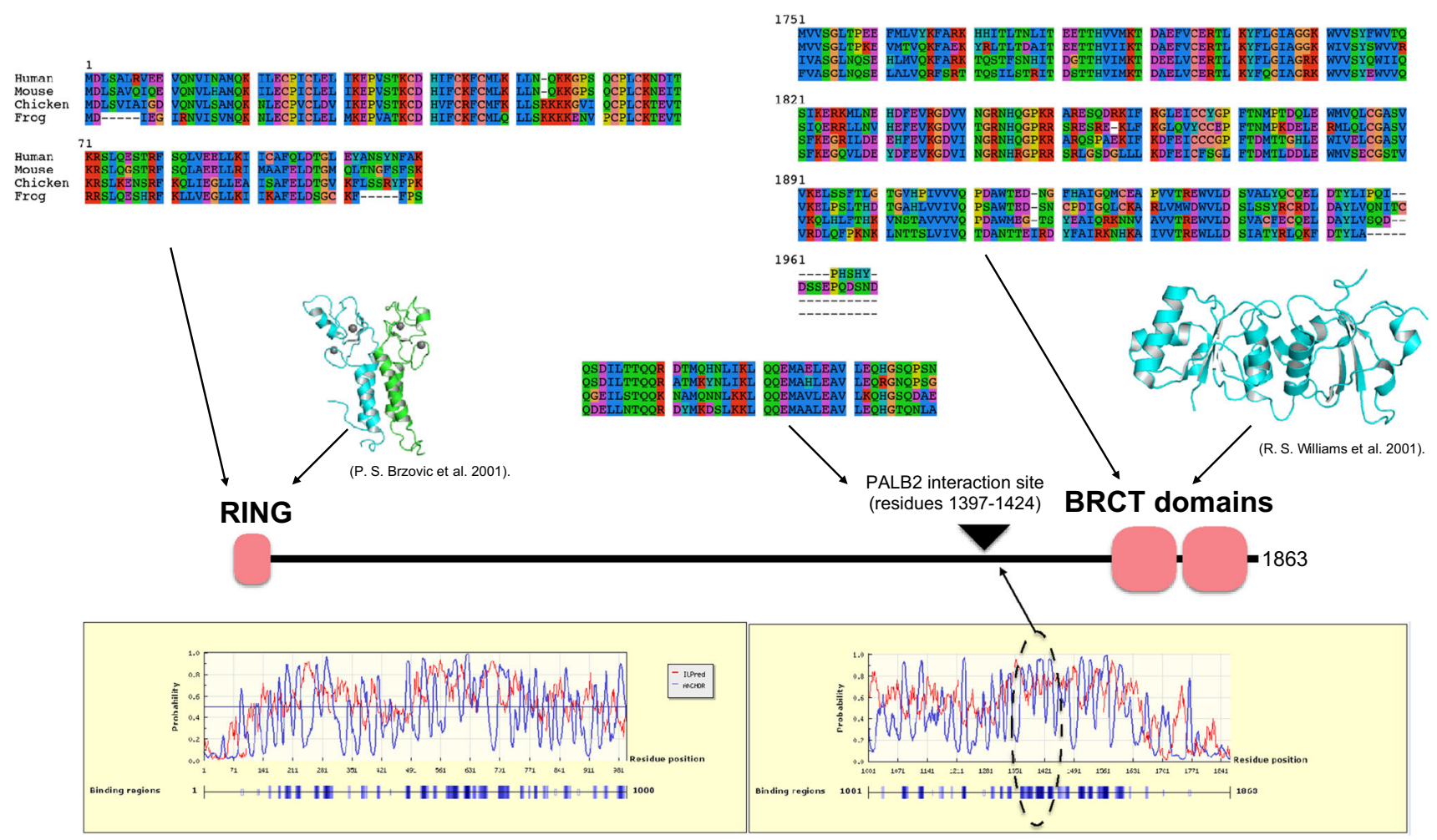

Fig. 9 Domains and interaction sites of BRCA1. The protein sequence alignment and crystal structures of the RING domain [76] and tandem BRCT domains [77] of BRCA1 are shown. The PALB2 interaction region is indicated, along with other potential interaction regions predicted by Anchor [75]

complex regulatory systems. The existence of many globular proteins or complexes that bind to multiple components (stages), systems that assemble to form rods and other cell structural elements (scaffolds), and areas of concerted folding and binding within intrinsically disordered regions that facilitate colocation of other globular proteins (strings) suggest that our model may be generic. If so, defining these properties will further explain how other multicomponent complexes are coordinated across space and time in cells and also guide future efforts to regulate these pathways. Such regulation may be possible through modulation of component colocation, particularly by targeting the sites where intrinsically disordered regions interact with globular proteins.

Acknowledgments T.O, Q.W, B.L.S, D.C and D.A were supported by a Wellcome Trust Programme Grant (application No. 093167/Z/ 10/Z. D.B.A received a C. J. Martin Research Fellowship from the National Health and Medical Research Council of Australia (APP1072476), and S.R.E was supported by a Gates Cambridge Scholarship.

Open Access This article is distributed under the terms of the Creative Commons Attribution 4.0 International License (http://crea tivecommons.org/licenses/by/4.0/), which permits unrestricted use, distribution, and reproduction in any medium, provided you give appropriate credit to the original author(s) and the source, provide a link to the Creative Commons license, and indicate if changes were made. 


\section{References}

1. O'Driscoll M, Jeggo PA (2006) The role of double-strand break repair-insights from human genetics. Nat Rev Genet 7(1):45-54

2. Lieber MR (2010) The mechanism of double-strand DNA break repair by the nonhomologous DNA end-joining pathway. Annu Rev Biochem 79:181-211. doi:10.1146/annurev.biochem.052308. 093131

3. Walker JR, Corpina RA, Goldberg J (2001) Structure of the Ku heterodimer bound to DNA and its implications for double-strand break repair. Nature 412(6847):607-614. doi:10.1038/35088000

4. Gell D, Jackson SP (1999) Mapping of protein-protein interactions within the DNA-dependent protein kinase complex. Nucleic Acids Res 27(17):3494-3502

5. Singleton BK, Torres-Arzayus MI, Rottinghaus ST, Taccioli GE, Jeggo PA (1999) The C terminus of Ku80 activates the DNAdependent protein kinase catalytic subunit. Mol Cell Biol 19(5):3267-3277

6. Spagnolo L, Rivera-Calzada A, Pearl LH, Llorca O (2006) Threedimensional structure of the human DNA-PKcs/Ku70/Ku80 complex assembled on DNA and its implications for DNA DSB repair. Mol Cell 22(4):511-519. doi:10.1016/j.molcel.2006.04. 013

7. Moshous D, Callebaut I, de Chasseval R, Corneo B, CavazzanaCalvo M, Le Deist F, Tezcan I, Sanal O, Bertrand Y, Philippe N, Fischer A, de Villartay JP (2001) Artemis, a novel DNA doublestrand break repair/V(D)J recombination protein, is mutated in human severe combined immune deficiency. Cell 105(2):177-186

8. Grawunder U, Wilm M, Wu X, Kulesza P, Wilson TE, Mann M, Lieber MR (1997) Activity of DNA ligase IV stimulated by complex formation with XRCC4 protein in mammalian cells. Nature 388(6641):492-495. doi:10.1038/41358

9. Buck D, Moshous D, de Chasseval R, Ma Y, le Deist F, Cavazzana-Calvo M, Fischer A, Casanova JL, Lieber MR, de Villartay JP (2006) Severe combined immunodeficiency and microcephaly in siblings with hypomorphic mutations in DNA ligase IV. Eur J Immunol 36(1):224-235. doi:10.1002/eji. 200535401

10. Ahnesorg P, Smith P, Jackson SP (2006) XLF interacts with the XRCC4-DNA ligase IV complex to promote DNA nonhomologous end-joining. Cell 124(2):301-313. doi:10.1016/j.cell.2005. 12.031

11. Sibanda BL, Chirgadze DY, Blundell TL (2010) Crystal structure of DNA-PKcs reveals a large open-ring cradle comprised of HEAT repeats. Nature 463(7277):118-121. doi:10.1038/ nature 08648

12. Ochi T, Wu Q, Chirgadze DY, Grossmann JG, Bolanos-Garcia VM, Blundell TL (2012) Structural insights into the role of domain flexibility in human DNA ligase IV. Structure 20(7):1212-1222. doi:10.1016/j.str.2012.04.012

13. Li Y, Chirgadze DY, Bolanos-Garcia VM, Sibanda BL, Davies OR, Ahnesorg P, Jackson SP, Blundell TL (2008) Crystal structure of human XLF/Cernunnos reveals unexpected differences from XRCC4 with implications for NHEJ. EMBO J 27(1):290-300. doi:10.1038/sj.emboj.7601942

14. Sibanda BL, Critchlow SE, Begun J, Pei XY, Jackson SP, Blundell TL, Pellegrini L (2001) Crystal structure of an Xrcc4DNA ligase IV complex. Nat Struct Biol 8(12):1015-1019. doi: $10.1038 / \mathrm{nsb} 725$

15. Wu Q, Ochi T, Matak-Vinkovic D, Robinson CV, Chirgadze DY, Blundell TL (2011) Non-homologous end-joining partners in a helical dance: structural studies of XLF-XRCC4 interactions. Biochem Soc Trans 39(5):1387-1392. doi:10.1042/BST0391387 (suppl 1382 p following 1392)
16. Ochi T, Gu X, Blundell TL (2013) Structure of the catalytic region of DNA ligase IV in complex with an Artemis fragment sheds light on double-strand break repair. Structure 21(4):672-679. doi:10.1016/j.str.2013.02.014

17. Ochi T, Blackford AN, Coates J, Jhujh S, Mehmood S, Tamura N, Travers J, Wu Q, Draviam VM, Robinson CV, Blundell TL, Jackson SP (2015) DNA repair. PAXX, a paralog of XRCC4 and $\mathrm{XLF}$, interacts with $\mathrm{Ku}$ to promote DNA double-strand break repair. Science 347(6218):185-188. doi:10.1126/science.1261971

18. Radhakrishnan SK, Jette N, Lees-Miller SP (2014) Non-homologous end joining: emerging themes and unanswered questions. DNA Repair (Amst) 17:2-8. doi:10.1016/j.dnarep.2014.01.009

19. Rambo RP, Tainer JA (2013) Accurate assessment of mass, models and resolution by small-angle scattering. Nature 496(7446):477-481. doi:10.1038/nature 12070

20. Blundell TL, Burke DF, Chirgadze D, Dhanaraj V, Hyvonen M, Innis CA, Parisini E, Pellegrini L, Sayed M, Sibanda BL (2000) Protein-protein interactions in receptor activation and intracellular signalling. Biol Chem 381(9-10):955-959. doi:10.1515/BC. 2000.117

21. Bolanos-Garcia VM, Wu Q, Ochi T, Chirgadze DY, Sibanda BL, Blundell TL (2012) Spatial and temporal organization of multiprotein assemblies: achieving sensitive control in informationrich cell-regulatory systems. Philos Trans A Math Phys Eng Sci 370(1969):3023-3039. doi:10.1098/rsta.2011.0268

22. Blaszczyk M, Harmer NJ, Chirgadze DY, Ascher DB, Blundell TL (2015) Achieving high signal-to-noise in cell regulatory systems: spatial organization of multiprotein transmembrane assemblies of FGFR and MET receptors. Prog Biophys Mol Biol 118(3):103-111. doi:10.1016/j.pbiomolbio.2015.04.007

23. Grundy GJ, Rulten SL, Zeng Z, Arribas-Bosacoma R, Iles N, Manley K, Oliver A, Caldecott KW (2013) APLF promotes the assembly and activity of non-homologous end joining protein complexes. EMBO J 32(1):112-125. doi:10.1038/emboj.2012. 304

24. Xing M, Yang M, Huo W, Feng F, Wei L, Jiang W, Ning S, Yan Z, Li W, Wang Q, Hou M, Dong C, Guo R, Gao G, Ji J, Zha S, Lan L, Liang H, Xu D (2015) Interactome analysis identifies a new paralogue of XRCC4 in non-homologous end joining DNA repair pathway. Nat Commun 6:6233. doi:10.1038/ncomms7233

25. Craxton A, Somers J, Munnur D, Jukes-Jones R, Cain K, Malewicz M (2015) XLS (c9orf142) is a new component of mammalian DNA double-stranded break repair. Cell Death Differ 22(6):890-897. doi:10.1038/cdd.2015.22

26. Jiang G, Plo I, Wang T, Rahman M, Cho JH, Yang E, Lopez BS, Xia F (2013) BRCA1-Ku80 protein interaction enhances endjoining fidelity of chromosomal double-strand breaks in the G1 phase of the cell cycle. J Biol Chem 288(13):8966-8976. doi:10. 1074/jbc.M112.412650

27. Wei L, Lan L, Hong Z, Yasui A, Ishioka C, Chiba N (2008) Rapid recruitment of BRCA1 to DNA double-strand breaks is dependent on its association with Ku80. Mol Cell Biol 28(24):7380-7393. doi:10.1128/MCB.01075-08

28. Futreal PA, Liu Q, Shattuck-Eidens D, Cochran C, Harshman K, Tavtigian S, Bennett LM, Haugen-Strano A, Swensen J, Miki Y et al (1994) BRCA1 mutations in primary breast and ovarian carcinomas. Science 266(5182):120-122

29. Chen Y, Farmer AA, Chen CF, Jones DC, Chen PL, Lee WH (1996) BRCA1 is a $220-\mathrm{kDa}$ nuclear phosphoprotein that is expressed and phosphorylated in a cell cycle-dependent manner. Cancer Res 56(14):3168-3172

30. Davis AJ, Chi L, So S, Lee KJ, Mori E, Fattah K, Yang J, Chen DJ (2014) BRCA1 modulates the autophosphorylation status of DNA-PKcs in $\mathrm{S}$ phase of the cell cycle. Nucleic Acids Res 42(18):11487-11501. doi:10.1093/nar/gku824 
31. Ropars V, Drevet P, Legrand P, Baconnais S, Amram J, Faure G, Marquez JA, Pietrement O, Guerois R, Callebaut I, Le Cam E, Revy P, de Villartay JP, Charbonnier JB (2011) Structural characterization of filaments formed by human Xrcc4-Cernunnos/ XLF complex involved in nonhomologous DNA end-joining. Proc Natl Acad Sci USA 108(31):12663-12668. doi:10.1073/ pnas. 1100758108

32. Hammel M, Rey M, Yu Y, Mani RS, Classen S, Liu M, Pique ME, Fang S, Mahaney BL, Weinfeld M, Schriemer DC, LeesMiller SP, Tainer JA (2011) XRCC4 protein interactions with XRCC4-like factor (XLF) create an extended grooved scaffold for DNA ligation and double strand break repair. J Biol Chem 286(37):32638-32650. doi:10.1074/jbc.M111.272641

33. Andres SN, Vergnes A, Ristic D, Wyman C, Modesti M, Junop M (2012) A human XRCC4-XLF complex bridges DNA. Nucleic Acids Res 40(4):1868-1878. doi:10.1093/nar/gks022

34. Andres SN, Modesti M, Tsai CJ, Chu G, Junop MS (2007) Crystal structure of human XLF: a twist in nonhomologous DNA end-joining. Mol Cell 28(6):1093-1101. doi:10.1016/j.molcel. 2007.10.024

35. Malivert L, Ropars V, Nunez M, Drevet P, Miron S, Faure G, Guerois R, Mornon JP, Revy P, Charbonnier JB, Callebaut I, de Villartay JP (2010) Delineation of the Xrcc4-interacting region in the globular head domain of cernunnos/XLF. J Biol Chem 285(34):26475-26483. doi:10.1074/jbc.M110.138156

36. Riballo E, Kuhne M, Rief N, Doherty A, Smith GC, Recio MJ, Reis C, Dahm K, Fricke A, Krempler A, Parker AR, Jackson SP, Gennery A, Jeggo PA, Lobrich M (2004) A pathway of doublestrand break rejoining dependent upon ATM, Artemis, and proteins locating to gamma-H2AX foci. Mol Cell 16(5):715-724. doi:10.1016/j.molcel.2004.10.029

37. Ma Y, Pannicke U, Schwarz K, Lieber MR (2002) Hairpin opening and overhang processing by an Artemis/DNA-dependent protein kinase complex in nonhomologous end joining and $\mathrm{V}(\mathrm{D}) \mathrm{J}$ recombination. Cell 108(6):781-794

38. Li S, Chang HH, Niewolik D, Hedrick MP, Pinkerton AB, Hassig CA, Schwarz K, Lieber MR (2014) Evidence that the DNA endonuclease ARTEMIS also has intrinsic $5^{\prime}$-exonuclease activity. J Biol Chem 289(11):7825-7834. doi:10.1074/jbc.M113.544874

39. Gu J, Li S, Zhang X, Wang LC, Niewolik D, Schwarz K, Legerski RJ, Zandi E, Lieber MR (2010) DNA-PKcs regulates a single-stranded DNA endonuclease activity of Artemis. DNA Repair (Amst) 9(4):429-437. doi:10.1016/j.dnarep.2010.01.001

40. Callebaut I, Moshous D, Mornon JP, de Villartay JP (2002) Metallo-beta-lactamase fold within nucleic acids processing enzymes: the beta-CASP family. Nucleic Acids Res 30(16):3592-3601

41. Huang Y, Giblin W, Kubec M, Westfield G, St Charles J, Chadde L, Kraftson S, Sekiguchi J (2009) Impact of a hypomorphic Artemis disease allele on lymphocyte development, DNA end processing, and genome stability. J Exp Med 206(4):893-908. doi:10.1084/jem.20082396

42. Dosztanyi Z, Csizmok V, Tompa P, Simon I (2005) The pairwise energy content estimated from amino acid composition discriminates between folded and intrinsically unstructured proteins. J Mol Biol 347(4):827-839. doi:10.1016/j.jmb.2005.01.071

43. Meszaros B, Simon I, Dosztanyi Z (2009) Prediction of protein binding regions in disordered proteins. PLoS Comput Biol 5(5):e1000376. doi:10.1371/journal.pcbi.1000376

44. Soubeyrand S, Pope L, De Chasseval R, Gosselin D, Dong F, de Villartay JP, Hache RJ (2006) Artemis phosphorylated by DNAdependent protein kinase associates preferentially with discrete regions of chromatin. J Mol Biol 358(5):1200-1211. doi:10.1016/ j.jmb.2006.02.061

45. Wang J, Aroumougame A, Lobrich M, Li Y, Chen D, Chen J, Gong Z (2014) PTIP associates with Artemis to dictate DNA repair pathway choice. Genes Dev 28(24):2693-2698. doi:10. 1101/gad.252478.114

46. Chen L, Morio T, Minegishi Y, Nakada S, Nagasawa M, Komatsu K, Chessa L, Villa A, Lecis D, Delia D, Mizutani S (2005) Ataxia-telangiectasia-mutated dependent phosphorylation of Artemis in response to DNA damage. Cancer Sci 96(2):134-141. doi:10.1111/j.1349-7006.2005.00019.x

47. Rulten SL, Cortes-Ledesma F, Guo L, Iles NJ, Caldecott KW (2008) APLF (C2orf13) is a novel component of poly(ADP-ribose) signaling in mammalian cells. Mol Cell Biol 28(14):4620-4628. doi:10.1128/MCB.02243-07

48. Cherry AL, Nott TJ, Kelly G, Rulten SL, Caldecott KW, Smerdon SJ (2015) Versatility in phospho-dependent molecular recognition of the XRCC1 and XRCC4 DNA-damage scaffolds by aprataxin-family FHA domains. DNA Repair (Amst) 35:116-125. doi:10.1016/j.dnarep.2015.10.002

49. Iles N, Rulten S, El-Khamisy SF, Caldecott KW (2007) APLF (C2orf13) is a novel human protein involved in the cellular response to chromosomal DNA strand breaks. Mol Cell Biol 27(10):3793-3803. doi:10.1128/MCB.02269-06

50. Kanno S, Kuzuoka H, Sasao S, Hong Z, Lan L, Nakajima S, Yasui A (2007) A novel human AP endonuclease with conserved zinc-finger-like motifs involved in DNA strand break responses. EMBO J 26(8):2094-2103. doi:10.1038/sj.emboj.7601663

51. Macrae CJ, McCulloch RD, Ylanko J, Durocher D, Koch CA (2008) APLF (C2orf13) facilitates nonhomologous end-joining and undergoes ATM-dependent hyperphosphorylation following ionizing radiation. DNA Repair (Amst) 7(2):292-302. doi:10. 1016/j.dnarep.2007.10.008

52. Wu LC, Wang ZW, Tsan JT, Spillman MA, Phung A, Xu XL, Yang MC, Hwang LY, Bowcock AM, Baer R (1996) Identification of a RING protein that can interact in vivo with the BRCA1 gene product. Nat Genet 14(4):430-440. doi:10.1038/ ng1296-430

53. Hashizume R, Fukuda M, Maeda I, Nishikawa H, Oyake D, Yabuki Y, Ogata H, Ohta T (2001) The RING heterodimer BRCA1-BARD1 is a ubiquitin ligase inactivated by a breast cancer-derived mutation. J Biol Chem 276(18):14537-14540. doi:10.1074/jbc.C000881200

54. Wu-Baer F, Lagrazon K, Yuan W, Baer R (2003) The BRCA1/ BARD1 heterodimer assembles polyubiquitin chains through an unconventional linkage involving lysine residue K6 of ubiquitin. J Biol Chem 278(37):34743-34746. doi:10.1074/jbc.C300249200

55. Matsuzawa A, Kanno S, Nakayama M, Mochiduki H, Wei L, Shimaoka T, Furukawa Y, Kato K, Shibata S, Yasui A, Ishioka C, Chiba N (2014) The BRCA1/BARD1-interacting protein OLA1 functions in centrosome regulation. Mol Cell 53(1):101-114. doi:10.1016/j.molcel.2013.10.028

56. Yu X, Chini CC, He M, Mer G, Chen J (2003) The BRCT domain is a phospho-protein binding domain. Science 302(5645):639-642. doi:10.1126/science. 1088753

57. Manke IA, Lowery DM, Nguyen A, Yaffe MB (2003) BRCT repeats as phosphopeptide-binding modules involved in protein targeting. Science 302(5645):636-639. doi:10.1126/science. 1088877

58. Rodriguez M, Yu X, Chen J, Songyang Z (2003) Phosphopeptide binding specificities of BRCA1 COOH-terminal (BRCT) domains. J Biol Chem 278(52):52914-52918. doi:10.1074/jbc. C300407200

59. Wu Q, Paul A, Su D, Mehmood S, Foo TK, Ochi T, Bunting EL, Xia B, Robinson CV, Wang B, Blundell TL (2016) Structure of BRCA1-BRCT/abraxas complex reveals phosphorylation-dependent BRCT dimerization at DNA damage sites. Mol Cell 61(3):434-448. doi:10.1016/j.molcel.2015.12.017

60. Thakur S, Zhang HB, Peng Y, Le H, Carroll B, Ward T, Yao J, Farid LM, Couch FJ, Wilson RB, Weber BL (1997) Localization 
of BRCA1 and a splice variant identifies the nuclear localization signal. Mol Cell Biol 17(1):444-452

61. Sy SM, Huen MS, Chen J (2009) PALB2 is an integral component of the BRCA complex required for homologous recombination repair. Proc Natl Acad Sci USA 106(17):7155-7160. doi:10.1073/ pnas.0811159106

62. Zhang F, Ma J, Wu J, Ye L, Cai H, Xia B, Yu X (2009) PALB2 links BRCA1 and BRCA2 in the DNA-damage response. Curr Biol 19(6):524-529. doi:10.1016/j.cub.2009.02.018

63. Cortez D, Wang Y, Qin J, Elledge SJ (1999) Requirement of ATM-dependent phosphorylation of brca1 in the DNA damage response to double-strand breaks. Science 286(5442):1162-1166

64. Greenberg RA, Sobhian B, Pathania S, Cantor SB, Nakatani Y, Livingston DM (2006) Multifactorial contributions to an acute DNA damage response by BRCA1/BARD1-containing complexes. Genes Dev 20(1):34-46. doi:10.1101/gad.1381306

65. Lee JS, Collins KM, Brown AL, Lee CH, Chung JH (2000) hCds1mediated phosphorylation of BRCA1 regulates the DNA damage response. Nature 404(6774):201-204. doi:10.1038/35004614

66. Xu B, Kim S, Kastan MB (2001) Involvement of Brcal in S-phase and $\mathrm{G}(2)$-phase checkpoints after ionizing irradiation. Mol Cell Biol 21(10):3445-3450. doi:10.1128/MCB.21.10.34453450.2001

67. Ruffner H, Jiang W, Craig AG, Hunter T, Verma IM (1999) BRCA1 is phosphorylated at serine 1497 in vivo at a cyclindependent kinase 2 phosphorylation site. Mol Cell Biol 19(7):4843-4854

68. Zhang J, Willers H, Feng Z, Ghosh JC, Kim S, Weaver DT, Chung JH, Powell SN, Xia F (2004) Chk2 phosphorylation of BRCA1 regulates DNA double-strand break repair. Mol Cell Biol 24(2):708-718

69. Graham TG, Walter JC, Loparo JJ (2016) Two-stage synapsis of DNA ends during non-homologous end joining. Mol Cell 61(6):850-858. doi:10.1016/j.molcel.2016.02.010

70. Reid DA, Keegan S, Leo-Macias A, Watanabe G, Strande NT, Chang HH, Oksuz BA, Fenyo D, Lieber MR, Ramsden DA,
Rothenberg E (2015) Organization and dynamics of the nonhomologous end-joining machinery during DNA double-strand break repair. Proc Natl Acad Sci USA 112(20):E2575-E2584. doi:10.1073/pnas.1420115112

71. Brouwer I, Sitters G, Candelli A, Heerema SJ, Heller I, de Melo AJ, Zhang H, Normanno D, Modesti M, Peterman EJ, Wuite GJ (2016) Sliding sleeves of XRCC4-XLF bridge DNA and connect fragments of broken DNA. Nature 535(7613):566-569. doi:10. 1038/nature 18643

72. Jubb H, Blundell TL, Ascher DB (2015) Flexibility and small pockets at protein-protein interfaces: new insights into druggability. Prog Biophys Mol Biol 119(1):2-9. doi:10.1016/j.pbio molbio.2015.01.009

73. Scott DE, Coyne AG, Venkitaraman A, Blundell TL, Abell C, Hyvonen M (2015) Small-molecule inhibitors that target proteinprotein interactions in the RAD51 family of recombinases. ChemMedChem 10(2):296-303. doi:10.1002/cmdc.201402428

74. Eustermann S, Brockmann C, Mehrotra PV, Yang JC, Loakes D, West SC, Ahel I, Neuhaus D (2010) Solution structures of the two PBZ domains from human APLF and their interaction with poly(ADP-ribose). Nat Struct Mol Biol 17(2):241-243. doi:10. 1038/nsmb.1747

75. Dosztanyi Z, Meszaros B, Simon I (2009) ANCHOR: web server for predicting protein binding regions in disordered proteins. Bioinformatics 25(20):2745-2746. doi:10.1093/bioinformatics/ btp518

76. Brzovic PS, Rajagopal P, Hoyt DW, King MC, Klevit RE (2001) Structure of a BRCA1-BARD1 heterodimeric RING-RING complex. Nat Struct Biol 8(10):833-837. doi:10.1038/nsb1001833

77. Williams RS, Green R, Glover JN (2001) Crystal structure of the BRCT repeat region from the breast cancer-associated protein BRCA1. Nat Struct Biol 8(10):838-842. doi:10.1038/nsb1001838 